\title{
IMPLEMENTASI METODE AMTSILATI DALAM MEMBACA KITAB KUNING DI PONDOK PESANTREN HIDAYATUL MUBTADIIN DEMAK
}

\author{
Wahyu Najib Fikri \\ Institut Agama Islam Negeri Salatiga, Indonesia \\ Email: najibfikri2@gmail.com
}

\begin{abstract}
The method of amtsilati is a method or tool used in reading and understanding the yellow book, where the book is a programmed and systematic book as well as a new breakthrough in facilitating reading the yellow book. The purpose of this study is to describe the application of amtsilati method in reading the yellow book, advantages and disadvantages in using the method of amtsilati in Pondok Pesantren Hidayatul Mubtadiin Demak. This type of research uses descriptive qualitative research type with case study research method. The results showed that the method of amtsilati is a new method of breakthrough to facilitate reading the yellow book. The advantages of the amtsilati method of the book of amtsilati is a programmed and printed lesson with a systematic arrangement.
\end{abstract}

Keywords: Amtsilati method, yellow book

\section{A. Pendahuluan}

Pesantren sebagai lembaga pendidikan Islam pertama di Indonesia telah banyak melahirkan generasi-generasi emas, pondok pesantren telah menorehkan tinta emas dalam peradaban sejarah bangsa Indonesia. ${ }^{1}$ Pesantren bukan saja lembaga tempat mencari dan menuntut ilmu tetapi juga tempat penggemblengan karakter pada diri santri, ketika lulus dari pesantran sang santri tersebut diharapkan dapat menerapkan ilmu pengetahuan dan dapat memberikan contoh dan teladan bagi masyarakat. Hal ini yang tidak terdapat dalam pendidikan umum, sekolah sekolah dan perguruan tinggi.

Pesantren merupakan suatu komunitas yang terdiri dari asrama atau pondok, masjid, kiyai, santri dan kitab kuning, hidup bersama dalam satu lingkungan pendidikan yang berlandaskan nilai-nilai agama Islam. Dengan demikian, lingkup pesantren

${ }^{1}$ Sonhaji Saleh, Dinamika Pesantren (Jakarta: CV Guna Aksara, 1988), 46 
Wahyu Najib Fikri: Implementasi Metode Amtsilati dalam Membaca Kitab Kuning...

merupakan suatu keluarga besar di bawah asuhan seorang kyai atau ulama yang dibantu oleh ustadz. ${ }^{2}$

Pondok pesantren di samping sebagai lembaga ilmu pengetahuan agama, juga merupakan lembaga perjuangan dan lembaga pelayanan masyarakat. Pada masa lalu para mu`allif (pengarang kitab) pada awalnya juga belajar dengan gurunya di pondok pesantren. Tujuan utama mereka belajar adalah untuk menjadikan kader-kader ulama yang mampu menguasai berbagai cabang ilmu pengetahuan antara lain: (1) melaksanakan ibadah kepada Allah SWT.; (2) memajukan pendidikan Islam dalam arti yang seluasluasnya (3) meningkatkan dakwah Islam (4) mewujudkan kesejahteraan umat Islam (5) membangun semangat untuk terlaksananya persatuan dalam kalangan umat Islam (6) melakukan kerjasama dengan organisasi lain guna memajukan Islam. ${ }^{3}$

Salah satu upaya untuk mempersiapkan para santri sebagai penerus ulama adalah dengan mampu membaca kitab kuning. Pada dasarnya kitab kuning adalah kitab yang berbahasa Arab tanpa baris dan arti yang biasanya kertasnya berwarna kuning yang dipergunakan oleh pondok-pondok salaf dalam mempelajari agama yang dikaji para santri dan dipimpin langsung oleh kyai, akan tetapi sekarang ada yang namanya kitab putih yang biasanya dipergunakan oleh perguruan tinggi dalam mengkaji ilmu-ilmu umum.

Dalam pembelajaran kitab kuning tentunya seorang pengajar (ustadz atau kyai) memegang peran penting, sebab dalam kegiatan belajar mengajar bersifat kompleks, yaitu bukan hanya menyampaikan pelajaran saja akan tetapi juga seorang guru mampu membuat peserta didik atau santri paham dalam mengkaji ilmu-ilmu yang telah diberikan oleh guru atau kyai dan diharapkan dapat mengaplikasikayna dalam kehidupan seharihari. Hal ini tidak terlepas untuk mengajarkan kepada mereka dalam membaca kitab kuning dengan baik dan benar sesuai dengan kaidah nahwu dan sharaf. Kendati demikian banyak sekali kendala-kendala yang muncul dalam mempelajari atau memahami kitab kuning, bagi para santri antara lain, karena belum memahami ilmu nahwu dan sharaf yang dijadikan sebagai alat atau kunci utama untuk membaca kitab kuning, sehingga dalam pembelajaran sangat lambat. Dengan demikian, sebagian tidak bisa memahami kitab kuning secara baik, sehingga pembelajaran kitab kuning tidaklah maksimal.

${ }^{2}$ Rofiq, Pemberdayaan Pesantren (Yogyakarta: PT. LKis Pelangi Aksara, 2005), 132

${ }^{3}$ Masyhud, Manajemen Pondok Pesantren (Jakarta: Diva Pustaka, 2003), 51 
Dalam pembelajaran yang telah diberikan oleh pondok pesantren kepada santrinya, sesungguhnya pondok pesantren telah mempergunakan kurikulum sebagai bahan rancangan kegiatan pembelajaran, yaitu dengan sistem pengajaran tuntas dengan menggunakan kitab sebagai pegangan dan sekaligus rujukan utama pondok pesantren. Menilik pesantren dewasa kini yang banyak menyesuaikan dengan tuntutan zaman dalam pembelajaranya seperti kurikulum yang banyak mengikuti anjuran pemerintah. Walaupun demikian banyak pesantren yang tetap memegang teguh sistem pembelajaranya baik klasikal maupun non klasikal. Adapun salah satu yang menjadi ciri khas pembelajaran di Pondok Pesantren Hidayatul Mubtadiin Demak adalah dengan menggunakan metode amtsilati yang disusun oleh K.H. Taufiqul Hakim salah seorang pendiri Pondok Pesantren Darul Falah Bangsri Jepara.

Metode amtsilati adalah suatu cara atau alat yang digunakan dalam membaca serta memahami kitab kuning, di mana kitab tersebut merupakan suatu kitab yang terprogram dan sistematis sekaligus menjadi terobosan baru dalam mempermudah membaca kitab kuning. ${ }^{4}$

Pembelajaran amtsilati dari pondok satu ke pondok yang lain tentunya mempunyai formulasi pengajaran dengan tujuan agar para santri dapat memahami membaca kitab kuning dengan mudah. Pengajaran amtsilati diberikan dalam pembelajaran di pesantren karena memang metode tersebut adalah metode cepat dalam memahami penjelasan dan tatacara membaca kitab kuning yang tertulis dengan bahasa Arab yang tidak ada syaklnya. ${ }^{5}$ Sehingga dengan belajar metode tersebut terutama nahwu dan sharaf diharapkan dapat memberikan bekal kepada para santri untuk dapat membaca kitab kuning.

Adapun alasan penulisan ini karena melihat banyaknya santri yang mondok di pesantren tersebut dan juga pesantren tersebut satu-satunya di Kabupaten Demak yang menggunakan metode amtsilati, dari sinilah penulis tertarik untuk memilih pesantren tersebut. Beberapa hal di atas yang kemudian melatarbelakangi penulis untuk mengkaji dan melakukan penulisan terhadap tema ini.

${ }^{4}$ Taufiqul Hakim, Amtsilati, Jilid 4 (Jepara: Al Falah Offset, 2004), 3

${ }^{5}$ Ibid. 
Wahyu Najib Fikri: Implementasi Metode Amtsilati dalam Membaca Kitab Kuning...

\section{B. Metode Penelitian}

Dalam melaksanakan penelitian ini penulis menggunakan penelitian kualitatif dengan menggunakan pendekatan fenomenologi. Dengan melakukan penyelidikan hatihati, sistematika dan terus-menerus terhadap suatu masalah dengan tujuan dapat digunakan untuk keperluan tertentu. ${ }^{6}$ Adapun data yang dikumpulkan dengan menggunakan data deskriptif yang berupa ucapan atau tulisan dan perilaku yang dapat diamati dari orang-orang. ${ }^{7}$ Tulisan ini berasal penelitian yang merupakan field reseach yang dibuktikan dengan keterlibatan peneliti di lapangan untuk menghayati berbagai pola pikir dan perilaku subyek penelitian. Untuk melakukan ini, penulis menggunakan pemahaman yang tidak memihak disertai dengan upaya menyerap dan mengungkapkan perasaan, motif, dan pemikiran di balik tindakan atau aktivitas subyek penelitian.

Sumber data pada tulisan ini terbagi menjadi dua, yaitu data primer dan data sekunder. Menurut Sugiyono, data primer adalah data yang dapat diperoleh langsung dari lapangan atau tempat penelitian dan juga sumber data yang langsung memberikan data kepada pengumpul data. ${ }^{8}$ Sedangkan data sekunder adalah data-data yang didapat dari sumber bacaan dan berbagai macam sumber lainnya yang terdiri dari surat-surat pribadi, buku harian, notulasi rapat perkumpulan, sampai dokumen-dokumen resmi dari berbagai instansi pemerintah.

Responden dalam penelitian ini adalah santri, ustadz dan kyai sementara yang menjadi fokus penelitianya yaitu pembelajaran kitab kuning yang berada di pesantren tersebut. Adapun teknik pengumpulan data yang digunakan adalah observasi. Metode observasi adalah suatu metode penelitian yang digunakan dengan jalan pengamatan suatu obyek dengan seluruh indra. Jadi observasi dapat dilakukan melalui penglihatan, pendengaran, pengecap dan peraba. ${ }^{9}$

Kedua, wawancara tehnik wawancara merupakan salah satu cara pengumpulan data dalam penelitian, karena menyangkut data maka wawancara menjadi elemen penting dalam proses penelitian. ${ }^{10}$ Tehnik pengumpulan data yang diperoleh dengan cara bertanya langsung kepada responden, untuk mendapatkan data tersebut penulis menggunakan

\footnotetext{
${ }^{6}$ Muh. Nazir, Metode Penelitian (Jakarta: Ghalia Indonesia, 1993), 87

${ }^{7}$ Arief Furchan, Pengantar Metode Penelitian Kualitatif (Surabaya: Usaha Nasional, 1992), 66 2006), 96

${ }^{8}$ Sugiono, Metode Penelitian Pendidikan Kuantitaf dan Kualitatif $R \& A$ (Bandung: Alfabeta,

${ }^{9}$ Suharsimi Arikunto, Prosedur Penelitian (Jakarta: Bina Aksara, 1998), 102

${ }^{10}$ Suyanto Bagong, Metode Penelitian Sosial (Jakarta: Fajar Interpratama Offset, 2006), 67
} 
metode wawancara mendalam kepada kyai atau pengasuh, ustadz, dan para santri, metode ini digunakan peneliti sebagai metode bantu dalam melakukan observasi. ${ }^{11}$ Yang bertujuan untuk menggali ketarangan-ketarangan dan informasi yang terkait dengan implementasi membaca kitab kuning dengan menggunakan metode amtsilati di Pondok Pesantren Hidayatul Mubtadiin Demak.

Ketiga, dokumentasi teknik pengumpulan data ini digunakan untuk menggali informasi dari media cetak, internet maupun dokumen-dokumen kepustakaan lainya yang mendukung erat dengan kaitanya masalah yang diteliti. Namun dalam penelitian kualitatif ini menggunakan pendekatan dokumen pribadi yaitu tempat orang mengungkap dengan kata-kata sendiri, pandangan mereka tentang seluruh kehidupan mereka atau beberapa aspek tentang mereka sendiri. ${ }^{12}$ Dokumen pribadi santri di atas antara lain, buku pelajaran, kitab yang digunakan sebagai bahan kajian amtsilati, kitab-kitab pelajaran para santri, serta hasil tes evaluasi santri baik berupa lisan maupun tulisan.

Pada analisis data ini peneliti menggunakan teknik analisis data kualitatif dalam mengolah data mentah dari lapangan untuk meningkatkan pemahaman tentang objek yang peneliti kaji. Analisis deskriptif-kualitatif merupakan suatu teknik yang menggambarkan dan menginterpretasikan arti data-data yang telah terkumpul dengan memberikan perhatian dan merekam sebanyak mungkin aspek situasi yang diteliti pada saat itu, sehingga memperoleh gambaran secara umum dan menyeluruh tentang keadaan sebenarnya. Menurut M. Nazir bahwa tujuan deskriptif ini adalah untuk membuat deskripsi, gambaran atau lukisan secara sistematis, faktual dan akurat mengenai faktafakta, sifat-sifat serta hubungan antar fenomena yang diselidiki. Dalam proses analisis data penelitian ini, peneliti menggunakan beberapa tahapan, yaitu mengelompokkan data yang diperoleh melalui observasi, kepustakaan, dokumentasi, wawancara mendalam, direkam setelah mendapatkan izin dari responden untuk kemudian ditranskip dan dipetakan berdasarkan kuisioner yang sudah ada. Kemudian peneliti menyeleksi dan menafsirkan data yang telah masuk dengan tujuan agar data tersebut dapat difahami dan dimengerti isi dan maksudnya. Kelanjutan dari tehnik ini adalah menginterpretasikan makna-makna yang tersirat di balik penjelasan responden. Dalam penelitian kualitatif, temuan atau data dapat dinyatakan valid apabila tidak ada perbedaan antara yang

${ }^{11}$ Lexy J. Moeloeng, Metodologi Penelitian Kualitatif (Bandung: PT Remaja Rosda Karya, 2002),

${ }^{12}$ Arief Furchan, Pengantar Metode Penelitian Kualitatif (Surabaya: Usaha Nasional, 1992), 69 
Wahyu Najib Fikri: Implementasi Metode Amtsilati dalam Membaca Kitab Kuning...

dilaporkan peneliti sesuai dengan apa yang terjadi pada obyek yang diteliti. Uji keabsahan data dalam penelitian kualitatif menggunakan triangulasi. Trianggulasi dalam pengujian keabsahan ini dari berbagai sumber dengan berbagai cara, dan berbagai waktu. Dengan demikian terdapat trianggulasi sumber, trianggulasi teknik pengumpulan data dan waktu.

\section{Implementasi Metode Amtsilati dalam Membaca Kitab Kuning}

Implementasi yaitu pemasangan, mempraktikkan dan pengenaan. ${ }^{13}$ Jadi yang dimaksud adalah mempraktikan rumus-rumus amtsilati yang digunakan untuk membaca kitab kuning. Dalam Kamus Besar Bahasa Indonesia, implementasi berati pelaksanaan atau Implementasi. Menurut Susilo, implementasi merupakan suatu ide, konsep, kebijakan, inovasi, dalam suatu tindakan praktis sehingga memberikan dampak baik berupa perubahan pengetahuan, keterampilan maupun nila dan sikap. ${ }^{14}$

Dalam tulisan ini, implementasi diartikan sebagai pelaksanaan atau implementasi dari metode amtsilati. Metode dalam bahasa Arab dikenal dengan istilah طريقة yang berarti jalan atau cara. ${ }^{15}$ Menurut Yamin, metode adalah cara melakukan atau, menyajikan atau menguraikan, memberi contoh, dan memberi latihan isi pelajaran kepada siswa untuk tujuan tertentu. ${ }^{16}$

Amtsilati adalah kata benda jama', sedangkan mufradnya (tunggal) mitsl yang artinya contoh. Pada kata amtsilah terdapat akhiran " $t i$ " seperti metode qira'ati, dan itu juga diilhami oleh buku cara membaca al-Qur'an, qira'ati; dan bertemu dengan " $y a$ "” mutakkalim wahdah ${ }^{17}$ Metode ini diberi nama amtsilati yang terinspirasi dari metode belajar cepat membaca al-Qur`an, yakni qira'ati. Jika dalam metode qira'ati orang bisa belajar membaca al-Qur`an dengan cepat, maka dengan metode amtsilati orang juga akan dapat membaca dan memahami kitab gundul (kitab tanpa harakat). Terbitlah nama amtsilati yang berarti "beberapa contoh dari saya" yang sesuai dengan akhiran " $t i$ " dari kata qira'ati.

\footnotetext{
${ }^{13}$ Sugiono, Metode Penelitian Pendidikan..., 92

${ }^{14}$ Susilo, Konsep Dasar Pendidikan Ilmu Pengetahuan Alam (IPA) (Makassar: Universitas Negeri Makassar, 2007), 174

${ }^{15}$ Islami SM., Strategi Pembelajaran Agama Islama Berbasis Paikem (Semarang: Rasail Media Group, 2009), 186

${ }^{16}$ Martinis Yamin, Desain Pemebelajaran Berbasis Tingkat Satuan Pendidikan (Jakarta: Putra Grafika, 2010), 213

${ }^{17}$ Taufiqul Hakim, 4
} 
Amtsilati adalah sebuah kitab yang disampaikan dengan metode amtsilati pula, yaitu metode praktis untuk mendalami al-Qur`an dan membaca kitab kuning bagi para pemula dengan menekankan contoh dan praktik hafalan.

Pada masa lalu, pengajaran kitab-kitab klasik terutama karangan ulama-ulama yang menganut paham Syafi'iyah merupakan satu-satunya pengajaran formal yang diberikan dalam lingkungan pesantren. Tujuan pengajaran ini adalah mencetak serta mendidik calon-calon ulama' ${ }^{18}$

Metode pembelajaran amtsilati adalah suatu cara yang digunakan dalam menyampaikan kitab Amtsilati, di mana kitab tersebut adalah kitab yang terprogram dalam sistematika penulisanya untuk belajar membaca kitab kuning. ${ }^{19}$ Metode amtsilati disusun karena mengingat betapa sulitnya dalam mepelajari ilmu nahwu sharaf yang diimplementasikan dalam membaca kitab kuning bagi tingkat pemula, baik di kalangan anak-anak maupun dewasa. Pembelajaran inilah yang disebut dengan pendidikan berbasis kompetensi (kemampuan). Metode tersebut digunakan dengan berlandaskan pada KBK (Kurikulum Berbasis Kompetensi) yang artinya bahwa program ini adalah lebih memfokuskan pada kompetensi santri dalam membaca kitab kuning dengan standar penguasaan kaidah-kaidah bahasa serta melakukan proses pemaknaan (ngesahi) baik menggunakan bahasa jawa maupun Indonesia.

Model yang digunakan dalam pembelajaran amtsilati ini adalah model pembelajaran klasikal. Model ini lebih menitikberatkan pada pembelajaran kelompok yang bertujuan untuk menciptakan suasana kondusif dalam proses belajar mengajar. ${ }^{20}$ Model pembelajaran klasikal yang diterapkan dalam metode amtsilati ini ditentukan dengan cara membentuk kelompok sesuai dengan jilid (tingkatan) masing-masing. Langkah-langkah dalam kegiatan belajar mengajar adalah (1) muqaddimah (2) penyajian materi (3) evaluasi (4) penutup.

Dengan pembelajaran model klasikal ini, proses belajar mengajar berlangsung efektif dan kondusif, sehingga tujuan pembelajaran dapat dicapai dengan maksimal. Selain itu dengan jumlah kelompok yang ideal maka seorang guru dapat memantau para santri dalam kegiatan belajar. Meskipun dengan menggunakan sistem klasikal, akan tetapi

\footnotetext{
${ }^{18}$ Zamakhsyari Dhofier, Tradisi Pesantren Studi tentang Pandangan Hidup Kyai (Jakarta: LP3ES, 2007), 151

${ }^{19}$ Taufiqul Hakim

${ }^{20}$ Ibid., 18
} 
Wahyu Najib Fikri: Implementasi Metode Amtsilati dalam Membaca Kitab Kuning...

pembelajaran ini lebih menekankan pada kemampuan individu dalam menguasai materi. Dengan kata lain, santri harus aktif dalam mengikuti pembelajaran serta tidak boleh bergantung kepada orang lain.

Pada tahap awal, Pondok Pesantren Hidayatul Mubtadi'in menggunakan metode amtsilati yang dilaksanakan sebagaimana pelajaran tambahan untuk menunjang para santri agar cepat dalam memahami gramatika bahasa Arab khususnya ilmu nahwu dan sharaf, kemudian sesuai dengan perkembangan zaman dan ide-ide untuk memfokuskan implementasi metode amtsilati terhadap pembelajaran kitab-kitab kuning agar para santri atau peserta didik lebih cepat memahami isi dan kandungan kitab kuning, yang termasuk salah satunya dalam pembelajaran kitab Ta'limul Muta'allim.

Sejauh pengamatan penulis, pembelajaran metode amtsilati dalam membaca kitab Ta'limul Muta'allim di Pondok Pesantren Hidayatul Mubtadi'in, ada beberapa hal yang harus dilakukan dalam implementasinya, antara lain: pertama, rumus qa idah, adalah intisari dalam kitab Amtsilati dari juz 1 sampai juz 5 dan dilengkapi dengan petunjuk dalam bentuk nazham yang ada pada khulashah.

Kedua, sharfiyah adalah kitab pendamping kitab Amtsilati yang target utamanya adalah mengetahui perubahan kata isthilahi atau lughawi. Di mana lughawi untuk mengetahui jumlah dan jenis pelakunya, sedangkan istilahi untuk mengetahui bentukbentuk lain yang sering digunakan, bila menemui kata-kata yang sulit maka dapat dicari dalam sharfiyah dengan cara mengkiaskan kata yang ada dan sejenisnya. Sharfiyah sendiri sering digunakan mulai jilid 4 untuk dijadikan tabel tashrifiyah karena sudah menginjak untuk mempelajari bab fi'il.

Ketiga, tatimmah merupakan kitab yang tidak kalah penting karena bersifat sebagai penyempurna, yang di dalamnya berisi tentang bagaimana implementasi rumus pada kata yang ditemui. Dalam implementasiya, tatimah merupakan kitab yang terpenting dalam menerapkan rumus amtsilati yaitu dapat diklasifikasikan dalam tiga langkah penting dalam praktik, yaitu: (1) menentukan titik atau koma beserta awal kalimat; (2) membahas kata perkata sampai titik atau koma berikutnya; (3) merangkai dan menerjemah dengan memperhatikan kaidah, bayangan dlamir, dzauq dan siyaq al-kalam. 
Dalam salah satu buku panduan metode amtsilati yaitu sharfiyah, di dalamnya dijelaskan bahwa satu kata dapat dikupas dari berbagai aspek, hingga dapat diuraikan dalam bentuk tashrif isthilahi atau lughawi serta i'lalnya.

Pembelajaran amtsilati ini ditargetkan 6 bulan bisa membaca kitab kuning dengan lancar tanpa syakal, akan tetapi di Pondok Pesantren Hidayatul Mubtadiin Demak dalam menerapkan metode amtsilati ini seorang santri dapat menempuhnya dalam kurun waktu 6 bulan sampai 2 tahun untuk dapat membaca kitab kuning.

Sistem evaluasi yang digunakan dalam metode amtsilati adalah diadakanya tes. Baik itu tes tertulis maupun tes lisan, yang dilaksanakan sebelum dan sesudah proses pembelajaran berlangsung dan juga ketika kenaikan jilid.

Model pembelajaran yang dilaksanakan dalam metode amtsilati ini adalah model pembelajaran klasikal. Model ini adalah model belajar secara berkelompok yang bertujuan untuk menciptakan suasana kondusif dalam proses belajar mengajar. Model pembelajaran klasikal yang diterapkan dalam metode amtsilati ini dengan cara membentuk kelompok yang ditentukan sesuai dengan jilidnya masing-masing. Dengan pembelajaran model klasikal ini, proses belajar mengajar berlangsung efektif dan kondusif, sehingga tujuan pembelajaran dapat dicapai dengan maksimal. Selain itu, dengan jumlah kelompok yang ideal, seorang guru dapat memantau langsung kemampuan santri masing-masing. Walaupun kegiatan pembelajaran dilaksanakan secara klasikal, tetapi pembelajaran ini lebih menekankan pada kemampuan individual dalam menguasai kompetensi (materi) yang dipersyaratkan. Dalam pembelajaran individual ini setiap santri diberi kesempatan untuk menguasai metode amtsilati sesuai dengan kecepatan dan kemampuan masing-masing. Dengan kata lain, santri harus aktif dalam mengikuti pelajaran serta tidak boleh bergantung pada orang lain. Untuk memperlancar proses belajar mengajar, tugas guru hanya mengarahkan, membimbing dan meluruskan santri jika melakukan kesalahan dalam mempelajari materi yang sedang dipelajari.

Untuk mencapai tujuan pembelajaran yang maksimal, pembelajaran di sini juga sangat memperhatikan perbedaan kemampuan santri dalam mengikuti proses belajar mengajar. Dalam hal ini, misalnya seorang santri yang belajar amtsilati dengan melihat atau membaca khulashah. Karena materi amtsilati diperbanyak dengan contoh-contoh alQur'an, maka dengan sendirinya santri akan hafal materi pada khulashah sesuai dengan kebutuhannya. Selain itu, adanya kegiatan setoran khulashah juga sangat mendukung 
Wahyu Najib Fikri: Implementasi Metode Amtsilati dalam Membaca Kitab Kuning...

bagi santri untuk cepat menghafalkan materi sesuai dengan kecepatan dan kemampuan mereka masing-masing. Dengan demikian, ketika santri sudah menguasai materi yang telah disampaikan, maka santri boleh mengajukan diri untuk dinilai (diuji) kompetensinya kapan saja bila mereka telah siap. Hal ini akan menguntungkan santri yang memiliki kemampuan lebih (pandai) karena dia boleh diuji lebih dulu setelah menguasai materi. Jika lulus, maka santri dapat melanjutkan ke jilid selanjutnya sehingga dapat khatam lebih cepat dibandingkan santri yang lain. Adapun untuk santri yang lamban dalam menerima pelajaran dan tidak lulus ujian berkesempatan untuk belajar lagi sampai dapat lulus pada jilid tersebut.

Dengan demikian, santri tersebut akan matang dalam memahami materi pelajaran. Dari uraian di atas dapat dipahami, bahwa pembentukan kelompok belajar dalam pembelajaran amtsilati ini sangat fleksibel karena bagi mereka yang telah lulus ujian dapat pindah ke kelompok belajar yang lain untuk melanjutkan pelajaran selanjutnya.

Kitab amtsilati merupakan sebuah kitab yang berisikan tentang materi pelajaran yang terprogram dengan penulisannya yang sistematis dan runtut, dalam mempelajari kitab kuning, bagi tahap pemula yang dilaksanakan dengan intensif dalam kurun waktu 3-6 bulan, akan tetapi dalam praktiknya pembelajaran dengan menggunakan metode amtsilati di Pondok Pesantren Hidayatul Mubtadiin Demak terprorgram dalam kurun waktu sampai 1 sampai 2 tahun, hal tersebut didasari karena dalam setiap tahunnya Pondok Pesantren Hidayatul Mubtadiin Demak mempunyai agenda sendiri dalam setiap tahunnya. Kitab tersebut membahas ilmu nahwu dan sharaf, kitab tersebut disusun karena mengingat betapa pentingnya belajar ilmu tersebut dan juga sebagai terobosan baru dalam membaca kitab kuning karena dirasa metode tersebut mudah untuk dipahami.

Metode pendidikan di pesantren pada umumnya masih menggunakan metode klasikal atau tradisional yaitu metode pembelajaran yang diselenggarakan menurut kebiasaan yang telah lama dilaksanakan di pesantren-pesantren pada umumnya atau bisa disebut juga sebagai metode asli (original). Dalam pembelajaran terjadi yang namanya pentransferan ilmu yang dilakukan oleh guru kepada murid atau santri. Dalam mengajar guru memegang peran penting, sebab mengajar bersifat kompleks, yakni bukan saja menyampaikan pelajaran akan tetapi juga menjadi figur atau contoh yang baik kepada murid atau santrinya dan diharapkan ilmu tersebut dapat diimplementasikan dalam kehidupan sehari-hari. 
Pada tahap awal, Pondok Pesantren Hidayatul Mubtadi'in menggunakan metodemetode klasikal seperti yang digunakan di pondok pesantren lainya, akan tetapi dalam perjalananya munculah metode amtsilati yang disusun oleh K.H Taufiqul Hakim di Pondok Pesantren Bangsri Jepara, hingga sampai sekarang di Pondok Pesantren Hidayatul Mubtadiin menggunakan metode amtsilati yang dilaksanakan sebagaimana pelajaran tambahan untuk menunjang para santri agar cepat dalam memahami gramatika bahasa Arab khususnya ilmu nahwu dan sharaf, kemudian sesuai dengan perkembangan zaman dan ide-ide untuk memfokuskan implementasi metode amtsilati terhadap pembelajaran kitab kuning agar para santri atau peserta didik lebih cepat memahami isi dan kandungan kitab kuning, yang termasuk salah satunya dalam implementasi kitab Ta'lim al-Muta'allim.

Dalam praktiknya dari hasil implementasi metode amtsilati dalam membaca kitab kuning di Pondok Pesantren Hidayatul Mubtadiin mayoritas santri dapat membaca kitab kuning dengan lancar dalam kurun waktu 1 tahun, akan tetapi juga tidak menutup kemungkinan sebagian santri juga banyak yang masih kesulitan dalam membaca kitab kuning, sehingga membutuhkan waktu yang sedikit lebih lama dibandingkan dengan santri yang lain dalam membaca kitab kuning.

Kemampuan santri dalam membaca kitab kuning dengan menggunakan metode amtsilati diukur dengan adanya tes, baik secara lisan maupun tulisan yang dilaksanakan sebelum dan sesudah pembelajaran kitab Amtsilati. Selain itu juga adanya tes kenaikan jilid, dalam tes kali ini terdapat standar nilai yang digunakan untuk kelulusan yaitu ketika telah mencapai nilai 9. Artinya ketika santri atau peserta didik telah mampu melampaui nilai standar yang telah ditentukan maka peserta didik tersebut boleh untuk naik ke jilid yang lebih tinggi, akan tetapi sebaliknya ketika peserta didik belum bisa mencapai standar nilai tersebut maka peserta didik wajib mengulang tes dan sekaligus mengulang jilid tersebut.

\section{Kesimpulan}

Metode amtsilati dinilai cukup efektif dalam kaitanya memahami qawa'id (nahwu dan sharaf) dan implementasiya dalam membaca kitab kuning. Hal ini terbukti dari beberapa unsur yang saling terkait satu dengan yang lainya. Unsur yang dimaksud yaitu adanya strategi, metode dan evaluasi. 
Wahyu Najib Fikri: Implementasi Metode Amtsilati dalam Membaca Kitab Kuning...

\section{E. Daftar Pustaka}

Saleh, Sonhaji. Dinamika Pesantren. Jakarta: CV Guna Aksara, 1988

Rofiq. Pemberdayaan Pesantren. Yogyakarta: PT. LKis Pelangi Aksara, 2005

Masyhud. Manajemen Pondok Pesantren. Jakarta: Diva Pustaka, 2003

Hakim, Taufiqul. Amtsilati. Jilid 4. Jepara: Al Falah Offset, 2004

Nazir, Muh. Metode Penelitian. Jakarta: Ghalia Indonesia, 1993

Furchan, Arief. Pengantar Metode Penelitian Kualitatif. Surabaya: Usaha Nasional, 1992

Sugiono Metode Penelitian Pendidikan Kuantitaf dan Kualitatif $R$ \& A. Bandung: Alfabeta, 2006

Arikunto, Suharsimi. Prosedur Penelitian. Jakarta: Bina Aksara, 1998

Bagong, Suyanto. Metode Penelitian Sosial. Jakarta: Fajar Interpratama Offset, 2006

Moeloeng, Lexy J. Metodologi Penelitian Kualitatif. Bandung: PT Remaja Rosda Karya, 2002

Furchan, Arief. Pengantar Metode Penelitian Kualitatif. Surabaya: Usaha Nasional, 1992

Susilo. Konsep Dasar Pendidikan Ilmu Pengetahuan Alam (IPA). Makassar: Universitas Negeri Makassar, 2007

Islami SM. Strategi Pembelajaran Agama Islama Berbasis Paikem. Semarang: Rasail Media Group, 2009

Yamin, Martinis. Desain Pemebelajaran Berbasis Tingkat Satuan Pendidikan. Jakarta: Putra Grafika, 2010

Dhofier, Zamakhsyari. Tradisi Pesantren Studi tentang Pandangan Hidup Kyai. Jakarta: LP3ES, 2007 